\title{
Supplementation of Inorganic and Organic Zinc Mixtures in Feed of Boerka Goats Fed by Oil Palm Fronds
}

\author{
Ginting SP, Antonius, Simanihuruk K \\ Indonesian Goat Research Station, PO Box 1, Galang, North Sumatera \\ E-mail: simonginting04@gmail.com \\ (received 10-03-2017; revised 26-06-2017; accepted 27-06-2017)
}

\begin{abstract}
ABSTRAK
Ginting SP, Antonius, Simanihuruk K. 2017. Suplementasi campuran Zn anorganik dan organik pada kambing Boerka yang diberi pakan pelepah kelapa sawit. JITV 22(2): 51-56. DOI: http://dx.doi.org/10.14334/jitv.v22i2.1798

Seng $(\mathrm{Zn})$ merupakan elemen pada berbagai jenis enzim maupun hormon yang memiliki peran fisiologis sangat penting di dalam tubuh, yang mempengaruhi produksi maupun reproduksi ternak termasuk aktivitas mikroba rumen dalam pemecahan serat pakan. Penelitian bertujuan untuk meningkatkan performa kambing yang diberi pakan dasar pelepah kelapa sawit yang mendapat suplementasi $35 \mathrm{ppm} \mathrm{Zn}$ dalam bentuk $\mathrm{Zn}$ anorganik $(\mathrm{ZnO})$ dan organic (Zn-metionin). Tiga puluh ekor kambing jantan persilangan Boer x Kacang (Boerka) umur 9-11 bulan digunakan dalam penelitian ini dan yang dibagi menjadi lima kelompok perlakuan pakan sebagai berikut: P1 (kontrol): pakan komplit berbasis pelepah sawit, P2: P1 + 35 ppm Zn (100\% ZnO), P3: P1 + 35 ppm Zn (75\% ZnO + 25\% Zn-metionin), P4: P1 + 35 ppm Zn (50\% ZnO + 50\% Zn-metionin), P5: P1 + 35 ppm Zn (25\% $\mathrm{ZnO}+75 \% \mathrm{Zn}$-metionin). Rancangan percobaan yang digunakan adalah Rancangan Acak Lengkap dengan enam ulangan. Peningkatan proporsi $\mathrm{Zn}$ organik meningkatkan konsumsi pakan dan konsumsi paling tinggi terdapat pada kelompok yang diberi suplementasi $\mathrm{Zn}$ anorganik/Zn organik dengan rasio $25 / 75$. PBBH hanya berbeda $(\mathrm{P}<0,05)$ pada kelompok yang mendapat suplementasi $\mathrm{Zn}$ dengan proporsi Zn-metionin paling tinggi $(75 \%)$. Konsentrasi $\mathrm{Zn}$ dalam darah meningkat secara nyata $(\mathrm{P}<0,05)$ dengan peningkatan proporsi Zn-metionine, namun komposisi asam lemak terbang tidak berbeda antar perlakuan $(\mathrm{P}>0,05)$. Disimpulkan bahwa performa kambing yang diberi pelepah sawit sebagai pakan dasar dapat ditingkatkan dengan pemberian suplemen $\mathrm{Zn}$ dalam bentuk campuran $\mathrm{Zn}$ anorganik $(\mathrm{ZnO})$ dan $\mathrm{Zn}$ organik (Zn-metionin)
\end{abstract}

Kata Kunci: Kambing, Seng, Suplementasi, Pelepah Sawit

\section{ABSTRACT}

Ginting SP, Antonius, Simanihuruk K. 2017. Supplementation of inorganic and organic zinc mixtures in feed of Boerka goats fed by oil palm fronds. JITV 22(2): 51-56. DOI: http://dx.doi.org/10.14334/jitv.v22i2.1798

Zinc is an element of many enzymes and hormones having very important physiological functions in the body so that it influences the production and reproduction of animals including the activity of the rumen microflora in degrading fiber in a diet. The aim of this study was to improve the performances of goats offered oil palm fronds based diets through the supplementation of $35 \mathrm{ppm}$ of $\mathrm{Zn}$ in the form of inorganic $(\mathrm{ZnO})$ and organic zinc ( $\mathrm{Zn}$-methionine). Thirty mature male crossing Boer $\mathrm{x}$ Kacang (Boerka) goats were divided into five groups and randomly allocated to one of the five feed treatments as follows: P1: complete feed based on the palm oil fronds (Control), P2: P1 + 35 ppm Zn (100\% Zn0), P3: P1 + 35 ppm Zn (75\% Zn0 + 25\% Znmethionine), P4: P1 + 35 ppm Zn (50\% Zn0 + 50\% Zn-methionine), P5: P1 + 35 ppm Zn (25\% Zn0 + 75\% Zn-methionine). The experiment was conducted in a Completely Randomized Design of six replications. Increasing the proportion of $\mathrm{Zn}$ methionine in the mixtures elevated feed consumption, and the highest feed intake was observed in goats received $75 \% \mathrm{Zn}$-methionine/25\% $\mathrm{ZnO}$. Daily body weight gains was only affected $(\mathrm{P}<0.05)$ by the $75 \% \mathrm{Zn}$-methionine $/ 25 \% \mathrm{ZnO}$ supplement. The concentration of $\mathrm{Zn}$ in the blood increased significantly $(\mathrm{P}<0.05)$ when $\mathrm{Zn}$ methionine was added and it increased steadily as the proportion of $\mathrm{Zn}$ methionine greater in the mixtures, but the VFA compositions of the rumen were not affected $(\mathrm{P}>0.05)$ by $\mathrm{Zn}$ supplementation. It is concluded that the performances of goat fed complete diets based on the oil palm fronds could be improved by supplementation of inorganic and organic $\mathrm{Zn}$ mixture.

Key Words: Goats, Zinc, Supplementation, Palm Oil Fronds

\section{INTRODUCTION}

Zinc (Zn) as a component of various enzymes or hormones plays crucial physiological role in the body influencing production and reproduction of animal (Supriyati 2013). It is also an enzyme component, plays a role in antioxidant system of body to eliminate volatile radicals resulted from metabolism process (Flora 2009; Zhao et al. 2014). Zinc is the second most element of micro mineral in the body, but cannot be saved in the body tissue, so that it should be available every time through the diet to meet physiological requirement of the animal (Zalewski et al. 2005; Swain et al. 2016). Maost $\mathrm{Zn}$ in the forage is distributed to cell 
wall (Whitehead et al. 1985; Cheng et al. 2012), so that influencing its availability for ruminant (Spears 2003). The assurance of adequate $\mathrm{Zn}$ intake is crucial in order to optimize the activity of fiber breaker enzyme in the rumen as the $\mathrm{Zn}$ function as cofactor. This role is more relevant in feeding system which uses oil palm frond as a basic diet consisting of high fiber with cellulose content of 49.8\% (Izzuddin 2008).

Inorganic $\mathrm{Zn}$ in the form of oxide zinc $(\mathrm{ZnO})$ or sulfate zinc $\left(\mathrm{ZnSO}_{4}\right)$ has been used as supplement for ruminant and those two inorganic zincs forms were reported having relatively comparable with the availability level (Jia et al. 2009; Jia et al. 2008). Organic $\mathrm{Zn}$ in the form of $\mathrm{Zn}$-methionine as methyl $\left(\mathrm{CH}_{3}\right)$ contributor is important in the DNA transcription and translation process. However, the use of organic $\mathrm{Zn}$ in ruminant diet is relatively limited due to higher price compared to the inorganic $\mathrm{Zn}$. On the other hand, the inorganic $\mathrm{Zn}$ availability is limited and indicating environmental pollution resulted from high dose requirement (Feng et al. 2009). So, this study was aimed to improve the performance of goat offered oil palm frond-based diet through $\mathrm{Zn}$ supplementation.

\section{MATERIALS AND METHODS}

\section{Experimental animal and diet}

As much of 30 mature males crossing Boer $x$ Kacang (Boerka) goats aged 9-11 months with the average body weight of $24.56 \pm 3.01 \mathrm{~kg}$ were used in this study. Those goats were weighed then divided into five groups of five treatments by supplementing $35 \mathrm{ppm} \mathrm{Zn}$ that consisted of inorganic $\mathrm{Zn}(\mathrm{ZnO})$ and organic $\mathrm{Zn}$ (Zn-methionine) as below:

P1: ZSAZxzspalm oil frond-based complete feed (Control)

P2: $\quad \mathrm{P} 1+35 \mathrm{ppm} \mathrm{Zn}(100 \% \mathrm{ZnO})$

P3: $\quad \mathrm{P} 1+35$ ppm $\mathrm{Zn}(75 \% \mathrm{ZnO}+25 \% \mathrm{Zn}-$ methionine)

P4: $\quad \mathrm{P} 1+35 \mathrm{ppm} \mathrm{Zn}(50 \% \mathrm{ZnO}+50 \% \mathrm{Zn}-$ methionine)

P5: $\quad$ P1 + 35 ppm Zn $(25 \% \mathrm{ZnO}+75 \% \mathrm{Zn}-$ methionine)

The goats were reared in the individual metabolic cage and treated with anti-parasite worm medicine. The complete feed consisted of Crude Protein by $17.9 \%$ and Digested Energy by $2630 \mathrm{Kcal} / \mathrm{kg}$ Dry Material (Table 1). Palm oil frond was used as fiber source in the complete feed by $30 \%$. The wheat of Indigofera zollingeriana leaf and soybean meal used as protein source. The ingredients were evenly mixed as complete feed. $\mathrm{Zn}$ supplement was processed by mixing the inorganic $\mathrm{Zn}$ (commercial) and organic $\mathrm{Zn}$ (Znmethionine) produced in Balai penelitian Ternak, Ciawi in the different ratio and same $\mathrm{Zn}$ concentration (35 $\mathrm{ppm})$. Zn supplement was then mixed with corn wheat as carrier $(25 \mathrm{~g})$ to ease the way of consumption. $\mathrm{Zn}$ supplement was fed in the morning and must be sure to be consumed. Complete feed then was provided ad libitum in the morning (08.30 am) and evening (02:00 pm)

The goat was fed with the diet and the left over diet were weighed every day to calculate daily consumption. The drinking water was given ad libitum. Goats were weighed every two weeks for 10 weeks to evaluate its body weight gain.

Table 1. Completed diet used in this research

\begin{tabular}{lc}
\hline \hline Feed ingredients & Proportion (\% BK) \\
\hline Indigofera zollingeriana leaf meal & 20.0 \\
Cake palm cake & 19.0 \\
Molasses & 5.0 \\
Soybean meal & 24.0 \\
Bone meal & 1.0 \\
Palm oil frond & 30.0 \\
Chemical composition ${ }^{\mathrm{a}}$ & \\
$\quad$ Crude Protein $(\% \mathrm{DM})$ & 17.9 \\
$\quad$ Digested energy $(\mathrm{Kkal} / \mathrm{kg} \mathrm{DM})$ & 2630 \\
\hline
\end{tabular}

${ }^{\mathrm{a} C}$ Counted. 


\section{Sample collection and analysis}

To evaluate the volatile fatty acid in the rumen, rumen liquid sample was collected using a tube inserted into rumen through esophagus of each goat. Samples were collected five hours after feeding at the end of feed test. Rumen liquid then was filtered using 4 layers of filter cloth and directly centrifuged $(10,000 \times \mathrm{x})$ for five minutes. The filtrate was then stored in a refrigerator $\left(-20^{\circ} \mathrm{C}\right)$ for further analysis. The VFA was analyzed using a Gas Chromatography. Blood sample $(10 \mathrm{ml})$ was collected from jugular vessel at the time rumen liquid collection. The sample then was separated by centrifuging at $1500 \mathrm{x} \mathrm{g} 40^{\circ} \mathrm{C}$ for 20 minutes. The plasma was then transferred into labeled tube and stored at $-20^{\circ} \mathrm{C}$ until further analysis.

\section{Statistical analysis}

This study was conducted under the Completely Randomized Design with five treatments and six repetitions. Data were analyzed using analysis of variance by SAS (2001). When there was a treatment effect, then the Duncan test was applied (Gomez \& Gomez 1984). The mathematical model used was:

$$
\mathrm{Y}_{\mathrm{ij}}=\mu+\tau_{\mathrm{i}}+\mathrm{e}_{\mathrm{ij}}
$$

Where:

$Y_{\mathrm{ii}}$ is variable response measured by the treatment- $\mathrm{i}$ $(i=1-5), \mu$ was general average value and the $e_{i j}$ is error random

\section{RESULTS AND DISCUSSION}

\section{Feed consumption and body weight gain}

Feed consumption (dry material) with inorganic $\mathrm{Zn}$ supplementation was not different $(\mathrm{P}>0.05)$ from the control (P1 vs. P2), even increased numerically (Table 2). Increasing organic $\mathrm{Zn}$ proportion tended to increase feed consumption and the highest consumption was on the administration of inorganic and organic zinc mixtures by $25 / 75$ of ration. The increase of feed consumption was suspected to relate to more $\mathrm{Zn}$ availability in rumen needed for enzymatic fiber degradation. One of restriction factors of consumption is the number and level of digestible fiber (NDF) in the rumen (Harper \& McNeill 2015). Consumption level of $\mathrm{DM}$ on the whole treatments was around $3.46-4.2 \%$ of body weight and was normal. This shows that complete feed can be used to improve palatability of oil palm fronds when it is supplemented as low basal diet (cafetaria style). The oil palm frond as fiber source is crucial to assure optimal rumen function.

The effect of $\mathrm{Zn}$ supplementation to daily weight gain (DWG) of goat was shown in the Table 2. The highest DWG $(\mathrm{P}<0.05)$ was from $\mathrm{P}$, while the DWG was not significantly different $(\mathrm{P}>0.05)$ among the control (P1) and P2, P3 and P4. This shows that increase of consumption of diet supplemented by $\mathrm{Zn}$ is expressed linearly with the body weight gain only on

Table 2. Consumption of completed diet and daily body weight gain of Boerka goat offered by inorganic and organic zinc mixtures with different ratio

\begin{tabular}{cccccc}
\hline \hline Parameter & P1 & P2 & P3 & P 4 & P5 \\
\hline Consumption: & & & & & $1098.3 \pm 89.7^{\mathrm{c}}$ \\
DM (g/d) & $857.8 \pm 78.5^{\mathrm{a}}$ & $906.5 \pm 85.1^{\mathrm{ab}}$ & $913.3 \pm 65.7^{\mathrm{b}}$ & $1025.6 \pm 81.5^{\mathrm{bc}}$ & $42.11 \pm 0.37^{\mathrm{c}}$ \\
DM (g/kg BW) & $34.61 \pm 4.7^{\mathrm{a}}$ & $37.27 \pm 4.67^{\mathrm{ab}}$ & $38.13 \pm 9.59^{\mathrm{b}}$ & $38.47 \pm 0.44^{\mathrm{bc}}$ & $4.2 \pm 0.51^{\mathrm{c}}$ \\
DM (\% BW) & $3.46 \pm 0.37^{\mathrm{a}}$ & $3.73 \pm 0.23^{\mathrm{ab}}$ & $3.81 \pm 0.84^{\mathrm{b}}$ & $3.84 \pm 0.78^{\mathrm{bc}}$ & 24.94 \\
Body Weight: & & & & 25.64 & 27.22 \\
Initial (kg) & 23.78 & 23.40 & 23.44 & 27.68 & $65.14 \pm 2.93^{\mathrm{b}}$ \\
Final (kg) & 25.78 & 25.24 & 24.46 & $58.29 \pm 3.21^{\mathrm{a}}$ & \\
PBBH (g) & $54.57 \pm 2.19^{\mathrm{a}}$ & $52.57 \pm 2.37^{\mathrm{a}}$ & $57.71 \pm 2.87^{\mathrm{a}}$ & & \\
\hline
\end{tabular}

$\mathrm{P} 1=$ Control (without supplementation)

$\mathrm{P} 2=\mathrm{P} 1+35 \mathrm{ppm} \mathrm{Zn}(100 \% \mathrm{Zn} 0)$

$\mathrm{P} 3=\mathrm{P} 1+35 \mathrm{ppm} \mathrm{Zn}(75 \% \mathrm{Zn} 0+25 \% \mathrm{Zn}$-methionine $)$

$\mathrm{P} 4=\mathrm{P} 1+35 \mathrm{ppm} \mathrm{Zn}(50 \% \mathrm{Zn} 0+50 \% \mathrm{Zn}$-methionine $)$

$\mathrm{P} 5=\mathrm{P} 1+35 \mathrm{ppm} \mathrm{Zn}(25 \% \mathrm{Zn0}+75 \% \mathrm{Zn}$-methionine $)$

$\mathrm{BW}=$ Body Weight 
the diet with the highest organic Zn composition. The average body weight gain of goat on the whole treatments was around $52-65 \mathrm{~g}$ and categorized into moderate. Jia et al. (2009) fed Z-methionine on goat by $20 \mathrm{ppm}$ and resulted daily weight gain by $42.7 \mathrm{~kg}$. Znmethionine supplementation on lamb as much as 30 and $60 \mathrm{ppm}$ resulted in daily weight gain each by $45 \mathrm{~g}$ and $55 \mathrm{~g}$ (Haryanto et al. 2005). Compared other study, the daily weight gain in this study indicated that the inorganic and organic zinc mixtures supplementation in the form of $\mathrm{Zn}$-methionine and $\mathrm{ZnO}$ could be added without reducing the growth response.

\section{Blood Zn Concentration and Volatile Fatty Acid of Rumen Liquid}

The effect of $\mathrm{Zn}$ supplementation on blood $\mathrm{Zn}$ content was shown in Figure 1. Blood $\mathrm{Zn}$ concentration of the control group without $\mathrm{Zn}$ supplementation (P1) was not different $(\mathrm{P}>0.05)$ compared to the one on the $100 \%$ inorganic $\mathrm{Zn}(\mathrm{ZnO})$ supplementation (P2). Supplementation of inorganic and organic zinc mixtures increased $\mathrm{Zn}$ content in the blood $(\mathrm{P}<0.05)$. This is proved that organic increased $\mathrm{Zn}$ availability was better than the inorganic $\mathrm{Zn}$. Supplementation of $25 \%$

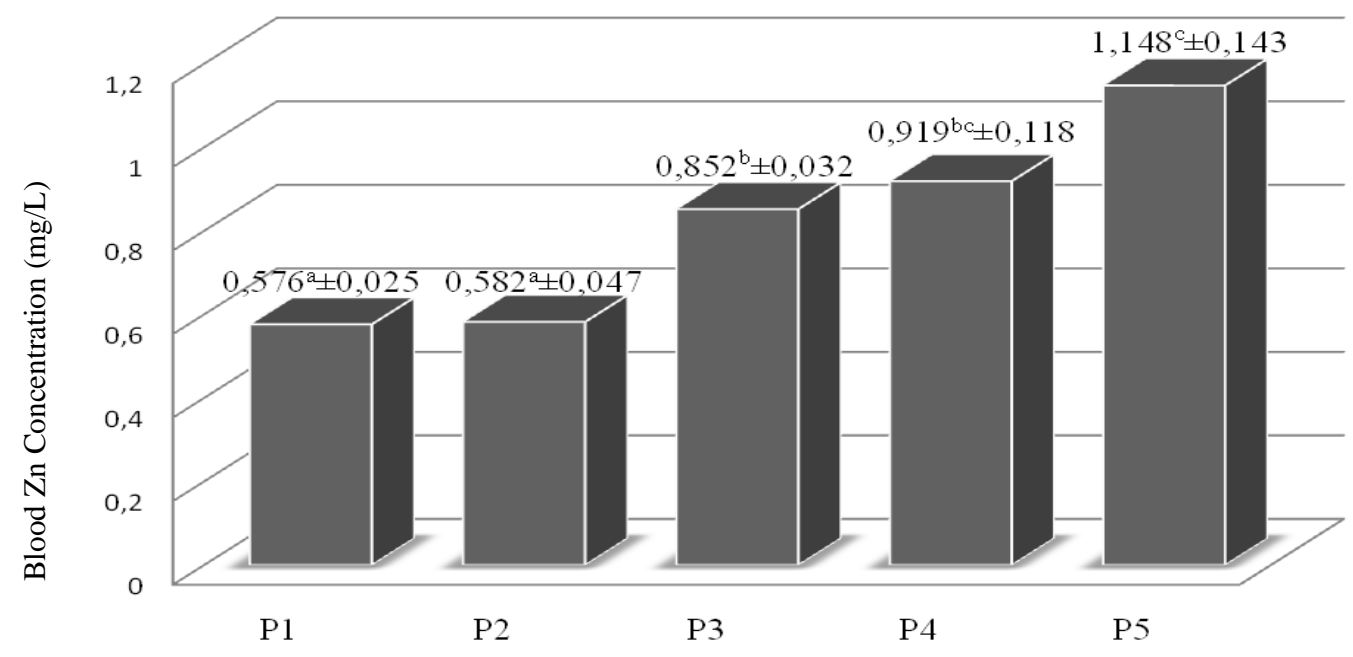

Figure 1. Effect of organic/inorganic $\mathrm{ZN}$ to Boerka goat blood $\mathrm{Zn}$ concentration offered by oil palm frond as basal diet.

$\mathrm{P} 1=$ Control (without supplementation);

$\mathrm{P} 2=\mathrm{P} 1+35 \mathrm{ppm} \mathrm{Zn}(100 \% \mathrm{Zn} 0)$;

$\mathrm{P} 3=\mathrm{P} 1+35 \mathrm{ppm} \mathrm{Zn}(75 \% \mathrm{Zn} 0+25 \% \mathrm{Zn}$-methionine);

$\mathrm{P} 4=\mathrm{P} 1+35 \mathrm{ppm} \mathrm{Zn}(50 \% \mathrm{Zn} 0+50 \% \mathrm{Zn}$-methionine $)$

$\mathrm{P} 5=\mathrm{P} 1+35 \mathrm{ppm} \mathrm{Zn}(25 \% \mathrm{Zn} 0+75 \% \mathrm{Zn}$-methionine $)$.

Different superscripts in the same column show significant $(\mathrm{P}<0.05)$.

Table 3. Volatile amino acid concentration of goat $(\mathrm{mM})$ without $\mathrm{Zn}$ or mixed-organic and inorganic $\mathrm{Zn}$ with different proportion

\begin{tabular}{lccccc}
\hline \hline Volatile amino acid $(\mathrm{mM})$ & $\mathrm{P} 1$ & $\mathrm{P} 2$ & $\mathrm{P} 3$ & $\mathrm{P} 4$ & $\mathrm{P} 5$ \\
\hline $\mathrm{C}_{2}$ & $25.50 \pm 4.63$ & $27.37 \pm 5.04$ & $27.65 \pm 4.38$ & $21.08 \pm 2.51$ & $24.34 \pm 1.88$ \\
$\mathrm{C}_{3}$ & $9.78 \pm 1.46$ & $9.73 \pm 2.42$ & $11.93 \pm 3.34$ & $8.73 \pm 0.76$ & $7.06 \pm 2.50$ \\
$\mathrm{iC}_{4}$ & $1.65 \pm 0.08$ & $1.61 \pm 0.25$ & $1.92 \pm 0.64$ & $1.98 \pm 1.11$ & $1.21 \pm 0.35$ \\
$\mathrm{nC}_{4}$ & $5.12 \pm 0.67$ & $5.93 \pm 1.82$ & $6.85 \pm 1.21$ & $4.31 \pm 0.27$ & $4.0 \pm 1.71$ \\
$\mathrm{iC}_{5}$ & $2.28 \pm 0.47$ & $1.84 \pm 0.56$ & $2.43 \pm 1.21$ & $2.07 \pm 1.08$ & $1.44 \pm 0.43$ \\
$\mathrm{nC}_{5}$ & $0.72 \pm 0.09$ & $0.71 \pm 0.15$ & $0.79 \pm 0.19$ & $0.60 \pm 0.16$ & $0.50 \pm 0.17$ \\
\hline
\end{tabular}

$\mathrm{P} 1=$ Control (without supplementation)

$\mathrm{P} 2=\mathrm{P} 1+35 \mathrm{ppm} \mathrm{Zn}(100 \% \mathrm{Zn} 0)$

$\mathrm{P} 3=\mathrm{P} 1+35 \mathrm{ppm} \mathrm{Zn}(75 \% \mathrm{Zn} 0+25 \% \mathrm{Zn}$-methionine $)$

$\mathrm{P} 4=\mathrm{P} 1+35 \mathrm{ppm} \mathrm{Zn}(50 \% \mathrm{Zn} 0+50 \% \mathrm{Zn}$-methionine $)$

$\mathrm{P} 5=\mathrm{P} 1+35 \mathrm{ppm} \mathrm{Zn} \mathrm{(25 \%} \mathrm{Zn0} \mathrm{+} \mathrm{75 \%} \mathrm{Zn-methionine})$ 
inorganic $\mathrm{Zn}$ and $75 \%$ organic $\mathrm{Zn}$ resulted in the highest content of $\mathrm{Zn}$ in the blood $(1148 \mathrm{mg} / \mathrm{L})$ and it is in accordance with the study of Jia et al. (2012) namely $1.17 \mathrm{mg} / \mathrm{L} \mathrm{Zn}$ in the goat blood supplemented by $100 \%$ $\mathrm{Zn}$-methionine (20 ppm) or is lower compared to study of Aditia et al. (2014): $2.97 \mathrm{mg} / \mathrm{L}$ of $\mathrm{Zn}$ by supplementing $200 \mathrm{mg}$ of $\mathrm{Zn}$.

The effect of $\mathrm{Zn}$ supplementation to the concentration of some volatile fatty acids of goat rumen was shown in the Table 3 . There was no effect $(\mathrm{P}>0.05)$ of treatments on the volatile fatty acid. Numerically, fatty acid $(\mathrm{C} 2)$ concentration on the P1 was equal to the other groups. Numerically, concentration of propionate acid (C3), isobutirate acid $\left(\mathrm{iC}_{4}\right)$ and iso-valerate acid $\mathrm{i}\left(\mathrm{C}_{5}\right)$ were comparable with all treatments. Composition of acetic acid, propionate acid and butyrate acid were 21.08-25.5, 7.06-11.93 and 1.21$1.98 \mathrm{mM}$, respectively.

A research conducted by Supriyati et al. (2012) showed an increase on fiber digestibility (neutral detergent fiber and acid detergent fiber) by addition of bio-complex $\mathrm{Zn}$ into the goat diet. Jia et al. (2012) reported that the effect of $\mathrm{Zn}$-methionine only influenced digestibility of acid detergent fiber and not on the neutral detergent fiber or dry material digestibility. In this study, there was no difference in volatile fatty acid composition that indicates the $\mathrm{Zn}$ supplementation used did not influence fiber digestibility.

\section{CONCLUSION}

Supplementation of $35 \mathrm{ppm} \mathrm{Zn}$ on oil palm frond for goat based diet did not increase the goat performance. Inorganic and organic zinc mixtures supplementation increased consumption, body weight gain and $\mathrm{Zn}$ concentration in the blood but did not affect the volatile fatty acid composition in rumen. An improvement of goat performance was in line with the higher $\mathrm{Zn}$-methionine proportion in the $\mathrm{Zn}$ mixture supplement.

\section{REFERENCES}

Aditia M, Sunarso, Seville CC, Angelo AA. 2014. Growth performans and mineral status of goats (Capra hircus Linn.) supplemented with zinc proteinate and selenium yeast. Int J Sci Eng. 7:124-129.

Cheng H, Tian G, Jia X, Zhu W, Yang J. 2012. Growth and $\mathrm{Cu}$ and $\mathrm{Zn}$ uptake of two forages grasses affected by application of vermicompost spiked with different metal contents. Afr J Agric Res. 39:5430-5437.
Feng M, Wang ZS, Zhou AG, Ai DW. 2009. The effects of different size of nanometer zinc oxide on the proliferation and cell integrity of mice duodenumepithelial cells in primary culture. Pak $J$ Nutr. 8:1164-1166.

Flora SJS. 2009. Structural, chemical, and biological aspects of antioxidants for strategies against metal and metalloid exposure. Oxidat Medic Cell Longev. 2:191-206.

Gomez KA, Gomez AA. 1984. Statistical procedures for agricultural research. 2nd ed. New York (USA): John Wiley \& Son

Haryanto B, Supriyati, Thalib A, Jarmani SN. 2005. Peningkatan nilai hayati jerami padi melalui bioproses fermentatif dan penambahan zinc organik. Mathius IW, Bahri S, Tarmuji, Prasetyo LH, Triwulaningsih E, Tiesnamurti B, Sendow I, Suhardono, editors. Proceeding of National Seminar on Livestock Production and Veterinary Technology. Bogor (Indones): Indonesian Center for Animal Research and Development. p. 473-478.

Harper KJ, McNeill DM. 2015. The role of iNDF in the regulation of feed intake and the importance of its assessment in Subtropical Ruminants System (the Role of iNDF in the Regulation of Forage Intake). Agriculture. 5:778-790

Izzuddin M. 2008. Oil palm frond (OPF) as an alternative source of pulp \& paper production material (Thesis). [Pahang (Malays): University Malaysia Pahang.

Jia W, Zu X, Zhang W, Cheng J, Guo C, Jia Z. 2009. Effects of supplemental zinc on performance, nutrient digestibility and plasma mineral profile in Cashmere goats. Asian-Aust J Anim Sci. 12:1648-1653.

Jia AB, Jia ZH, Zhang W, Wang RL, Zhang SW, Zhu XP. 2008. Effects of dietary zinc on performances and nutrient digestibility and plasma zinc status of Cashmere goats. Small Rumin Res. 80:68-72.

[SAS] Statistical Analysis System. 2001. SAS/STAT user's guide (Release 9.1.3). North Carolina (USA): SAS Institute.

Spears JW. 2003. Trace mineral bioavailability in ruminants. J Nutr. 133:1506S-1509S.

Supriyati. 2013. Seng organik sebagai imbuhan pakan ruminansia. Wartazoa. 23: 142-157

Supriyati, Budiarsana IGM, Puastuti W, Sutama IK. 2012. Effect of supplementation of Comin+ and $\mathrm{Zn}$ biocomplex on performance goats. JITV. 17:290-296.

Swain PS, Rao SBN, Rajendran D, Dominic G, Selvaraju S. 2016. Nano zinc, an alternatif to conventional zinc as animal feed supplement: A review. Anim Nutr. 2:134-141. 
Whitehead DC, Goulden KM, Hartley RD. 1985. The distribution of nutrient elements in cell wall and other fractions of the herbage of some grasses and legumes. J Sci Food Agric. 36:311-318.

Zalewski PD, Ai QT, Dion G, Lata J, Chiara M, Richard ER. 2005. Zinc metabolism in airway epithelium and airway inflammation: basic mechanisms and clinical targets: a review. Pharmacol Ther. 105:127-149.
Zhao CY, Tan SX, Xiao XY, Qiu XS, Pan JQ, Tang ZX. 2014. The effect of dietary zinc oxide nanoparticles on growth performance and antioxidative status in broiler. Biol Trace Elem Res. 160:361-367. 